\title{
A LITERATURE REVIEW OF NITROGEN AVAILABILITY INDICES FOR USE IN URBAN LANDSCAPES
}

\author{
by Bryant C. Scharenbroch ${ }^{1}$ and John E. Lloyd ${ }^{2}$
}

\begin{abstract}
Managers of urban landscapes are required to maintain aesthetic qualities of plants and so must ensure that vegetation has adequate nitrogen to grow and thrive. Soil organic matter decomposition and nitrogen mineralization facilitated by soil microorganisms are the primary determinants of soil nitrogen availability. Therefore, investigations of soil nitrogen pools, organic matter, and soil microbial populations should help urban landscape managers refine diagnostic tools and prescription fertilization for urban vegetation. Foliar assessments can be used to measure nitrogen the plant has acquired, but such assessments do not reveal information about current or future plant nitrogen acquisition. Soil nitrogen analyses can be used to measure the current nitrogen available for plant uptake as well as the amount that will potentially be available at some time in the future. Total soil organic matter changes occur primarily particulate organic matter (POM) fractions, and positive correlations have been identified between POM nitrogen, soil microbial nitrogen, and potentially mineralizable nitrogen. Consequently, examinations of POM fractions potentially indicate changes in soil organic matter and nitrogen availability. To improve existing standards for determining nitrogen status and needs of urban landscape plants, soil and plant nitrogen evaluation must be improved and correlated with plant nitrogen demand and soil nitrogen supply.

Key Words. Soil organic matter; particulate organic matter; soil nitrogen cycle; plant-available nitrogen; nitrogen mineralization; microbial biomass nitrogen; plant nitrogen diagnosis; soil nitrogen diagnosis.
\end{abstract}

\section{TERRESTRIAL NITROGEN CYCLING}

Plant establishment and survival is often determined by interactions with soil in a bottom-up manner; thus, soils directly impact many plant characteristics (Hutchinson 1959; Hairston et al. 1960; Herms and Mattson 1992; Robinson 1996). Soil nitrogen mineralization and availability has a direct and significant influence on plant vitality (Schulze 1982; McDonald et al. 1986a, 1986b; Millard and Proe 1992; Ericsson et al. 1996; McAlister and Timmer 1998; Zerihun et al. 1998; Rose 1999; Rosati et al. 2000; Neilsen et al. 2001; Anttonen et al. 2002; Clinton et al. 2002; Kraus et al. 2002). Nitrogen is the most limiting element in temperate terrestrial systems (Vitousek and Howarth 1991; Aber 1992; Harris 1992). Nitrogen is the fourth most abundant plant element, and it is an essential component of proteins, nucleic acids, hormones, and chlorophyll (Kozlowski 1985; Hopkins 1999). Although the plant nitrogen demand is large, the supply of nitrogen available for uptake is often small. Of the total global nitrogen, $99.96 \%$ is in the atmosphere as $\mathrm{N}_{2}$ gas, and of the remaining $0.04 \%$, only $6.5 \%$ ( $0.0026 \%$ of the global nitrogen) is in forms that plants can acquire from the soil and use for physiological functioning (Jaffe 1992).

Nitrogen is cycled among terrestrial plants, soil, and microorganisms (Figure 1). Nitrogen enters the terrestrial system through biological or industrial fixation, atmospheric deposition, or fertilization. Nitrogen is fixed in the soil lattices, oxidized, and assimilated by plants or microorganisms, or lost from the terrestrial system (Evangelou 1998). Nitrogen assimilation by plants occurs directly through root uptake or indirectly through mycorrhizal association. Microbial assimilation of mineral nitrogen is referred to as immobilization. Upon death, senescence, exudation, or excretion, nitrogen enters the soil organic matter pool. As much as $90 \%$ of terrestrial nitrogen occurs as soil organic matter (Pulford 1991). Soil organic matter is decomposed by microorganisms, mainly fungi and actinomycetes, and nitrogen is transferred into organic nitrogen components. Dissolved organic nitrogen (DON) is then used and converted to mineral nitrogen $\left(\mathrm{NH}_{4}^{+}, \mathrm{NO}_{3}^{-}\right.$, or $\left.\mathrm{NO}_{2}^{-}\right)$by other soil organisms, mainly bacteria, through the process of mineralization. Specifically, mineralization is the production of $\mathrm{NH}_{3}$ or $\mathrm{NH}_{4}^{+}$through microbial decomposition (Evangelou 1998). Studies have also found that dissolved organic nitrogen can be directly or indirectly acquired by plants (Nasholm et al. 1998; Jones and Kielland 2002).

Terrestrial nitrogen losses occur as a result of volatization, dentrification, runoff, and leaching. Excess soil ammonium $\left(\mathrm{NH}_{4}^{+}\right)$remaining after plant and microbial uptake can be oxidized by Nitrosomonas and Nitrospira bacteria through nitrification processes into nitrite $\left(\mathrm{NO}_{2}{ }^{-}\right)$, and it is oxidized again into nitrate $\left(\mathrm{NO}_{3}^{-}\right)$by a nitrobacter bacterium (Evangelou 1998). In certain instances, such as high $\mathrm{pH}$, low cation exchange capacity (CEC), or excessive $\mathrm{NH}_{4}{ }^{+}$, a substantial amount of ammonium may volatize as ammonia gas $\left(\mathrm{NH}_{3}\right)$. In conditions of low oxygen availability, nitrate not taken up by plants or microorganisms can be 


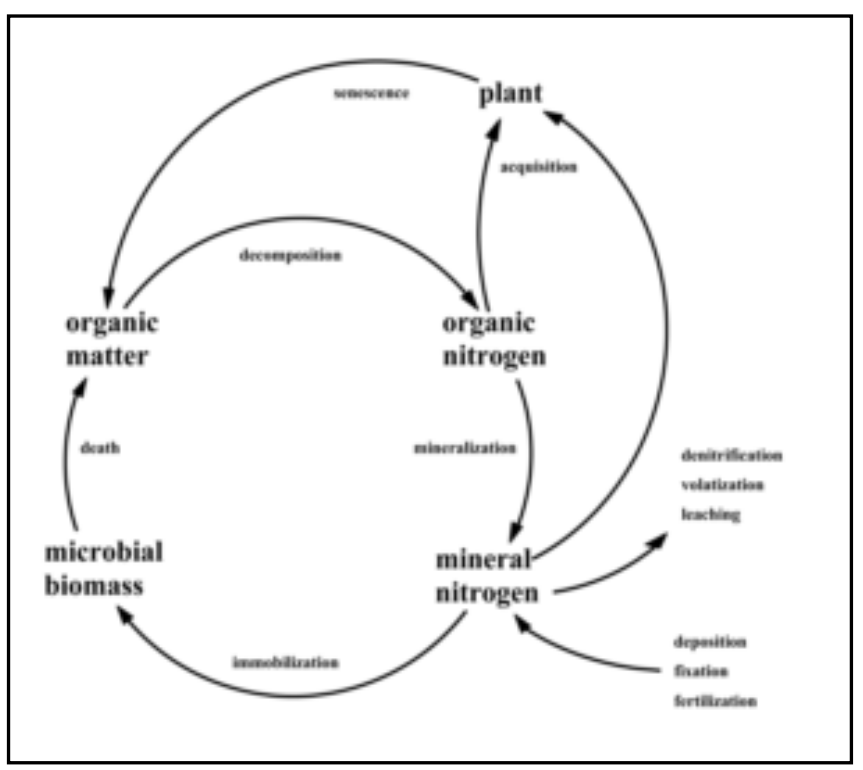

Figure 1. Plant and soil cycling, inputs, and outputs of nitrogen in terrestrial urban ecosystems. Nitrogen enters the terrestrial cycle through industrial fixation, atmospheric fixation and deposition, or fertilization. Decomposing organic matter releases organic nitrogen that is mineralized into nitrogen that is available for plant and microbial uptake. Nitrogen acquired by microbes is immobilized and not available for plant uptake. Nitrogen from plants and microbes is returned to soil upon death, senescence, exertion, or exudation. Nitrogen leaves the terrestrial cycle through denitrification, volatization, and leaching.

further reduced through denitrification by Pseudosomonas thiobacillus and Micrococcus denitrificans bacteria (Zhu and Carreiro 1999). Nitrogen, mostly as $\mathrm{DON}$ or $\mathrm{NO}_{3}^{-}$, can be lost from the terrestrial system as a result of runoff and leaching.

Soil mineralization and immobilization processes determine the plant-available nitrogen pool. The equilibrium between mineralization and immobilization is influenced by such factors as temperature, moisture, oxygen, microbial populations, and the carbon and nitrogen contents of the organic material (Evangelou 1998). For instance, net mineralization is generally expected with the relatively low carbon-to-nitrogen ratio (C:N) of organic material. Nitrogen immobilization has been found to occur when C:N exceeds values of 20:1 to 25:1 (Paul and Clark 1989; Sims 1990; Shiralipour et al. 1992; Burgess et al. 2002; Herms et al. 2002; Sullivan et al. 2002).

\section{URBAN IMPACT ON TERRESTRIAL NITROGEN CYCLING}

The urban terrestrial nitrogen cycle is altered by changes in physical, chemical, and biological properties of urban soils
(Craul 1985; Pulford 1991; Craul 1993; Beyer et al. 1995; Craul 1999). Soil formation and development occurs through the interaction of climate, organisms, relief, parent material, and time (Jenny 1941). In urban environments, humans alter these soil-forming factors by impacts associated with urban infrastructure and soil management practices. Most urban soils are modified or replaced in order to meet the demands of urban infrastructure (Bullock and Gregrory 1991; Craul 1993; Huinink 1998; Craul 1999; Fenton and Collins 2000; Harris et al. 2004). For instance, building specifications often result in the scraping, compacting, and covering of urban soils, which can impact soil organic matter, texture, structure, bulk density, infiltration, aeration, root penetration, and biological activity. As a result of impacts associated with urban infrastructure, arborists and urban landscape managers perform remedial management actions to make urban soils more suitable plant-growing environments. Remedial soil management actions include irrigation, aeration, radial trenching, mulching, and fertilization, all of which further alter the physical, chemical, biological properties, and, thus, the nitrogen status of urban soils.

Questions remain as to whether various impositions on soil properties predispose urban soils to be nitrogen deficient. Research is necessary to identify nitrogen supply and demand specifics in a variety of urban environments. Assessing nitrogen demand can be difficult because it varies with the wide range of plant species, ages, and physiological and phenological conditions in urban environments (Marion 2000; Siewert et al. 2000). Nitrogen acquisition by plants has been studied primarily in forest and agricultural production systems (Magdoff 1991; Cole 1995). Comparatively little research has addressed plant nitrogen demands in urban systems. Studies in agriculture and forestry have shown that corn will remove roughly $170 \mathrm{~kg} \mathrm{~N} \mathrm{ha}^{-1}$ (3.5 lb N $1,000 \mathrm{ft}^{-2}$ ) over one growing season (Magdoff 1991) and that $80 \mathrm{~kg} \mathrm{~N} \mathrm{ha}^{-1}$ (1.3 lb N 1,000 ft-2) (Cole 1995) is needed for good growth of western conifers. A study that examined established shade tree growth recommended adding 134 to

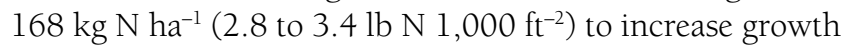
of established shade trees (Van der Werken 1981). Most studies of plant nitrogen demand have focused on plant growth responses to nitrogen additions. Consequently, fertilization recommendations are based on plant growth response data rather than on plant health characteristics or soil nitrogen availability (Rose 1999). Nitrogen demands to increase growth may differ from demands to maintain healthy, more vigorous plants (Herms and Mattson 1992).

Few studies have assessed soil nitrogen supply in urban landscapes, and most assessed either total or mineral nitrogen. These studies found wide ranges of total soil nitrogen, 2,520 to 10,574 $\mathrm{kg} \mathrm{N} \mathrm{ha}^{-1}$ (51 to $214 \mathrm{lb} \mathrm{N} \mathrm{1,000}$ $\mathrm{ft}^{-2}$ ) (Roberts and Roberts 1984; Beyer et al. 1995) and mineral nitrogen, 27 to $281 \mathrm{~kg} \mathrm{~N} \mathrm{ha}^{-1}(0.55$ to $5.7 \mathrm{lb} \mathrm{N}$ 
1,000 ft ${ }^{-2}$ ) (Roberts and Roberts 1984; Goldman et al. 1995; Zhu and Carreiro 1999). Measurements of total soil nitrogen tend to overestimate plant-available nitrogen, because much of the soil nitrogen is found in forms that plants cannot readily acquire (Mulvaney and Khan 2001). For example, Palmer and Chadwick (1985) found that as much of $25 \%$ of total soil nitrogen is found tied up within the clay lattices. Additionally, soil nitrogen found associated with recalcitrant organic matter and microbial biomass is unavailable for immediate plant uptake (Evangelou 1998). Measures of mineral nitrogen are also of little use because mineral nitrogen is extremely susceptible to environmental conditions such as temperature, moisture, and microbial activity (Mader and Cook 1982). Additionally, mineral nitrogen measurements include what is available for uptake not only by plants but also soil microorganisms (Evangelou 1998).

Currently, research has not adequately examined urban soil nitrogen status, but urban soils are commonly perceived to be nitrogen deficient. This perception arises from observations that organic matter is lost in urban landscapes through litter removal and from topsoil oxidation, erosion, and removal (Pulford 1991; Craul 1999; Harris et al. 2004). However, urban soil organic matter gains may be just as prevalent as a result of organic inputs from grass clippings and leaf litter left on site, root turnover, mulching, composting, and additions of topsoil. Nonetheless, to overcome these perceived urban soil nitrogen deficiencies, tree fertilization is commonly performed in urban landscapes. A study by Varlamoff et al. (2001) found that $66 \%$ of Georgia homeowners fertilize their trees, but this survey did not identify whether a soil or plant analysis was performed prior to fertilization.

\section{NITROGEN FERTILIZATION OF URBAN TREES}

Fertilization of landscape trees was first recorded in the 1600s when nutrients were provided by inserting fertilizer into soil holes (Gerhold 2002). As a way of enhancing tree growth, arboriculture expanded in the early 1900s from repair and pruning to include fertilization. Fertilization has a much longer history in nonurban systems. Agriculture and horticulture crop production have long used fertilization to increase yields. The success of an agricultural crop may depend on fertilizer efficiency; thus, much research has been devoted to examining fertilizer use efficiency on a wide range of commodities (Stamatiadis et al. 1999). Fertilizers are used in orchards to ensure continuous and profitable fruit production (Bondada et al. 2001; Johnson et al. 2001; Kraimer et al. 2001; Niederholzer et al. 2001; Weinert et al. 2002). In forestry, fertilizers are used as a silvicultural management tool and can be used to increase the production and survival of tree seedlings (Mugasha and Pluth 1994; Sikstrom et al. 1998; Cabrera and Devereaux 1999; Hangs et al. 2003). Fertilizers have been used in nursery and Christmas tree production to increase plant establishment and growth for aesthetically marketable products (Yeager and Wright 1981; Warren 1993; Rose and Biernacka 1999; Rose et al. 1999; Broschat and Klock-Moore 2000; Hinesley et al. 2000). Because of a lack of research on urban plant nitrogen demands and soil nitrogen supply, fertilization recommendations from nonurban systems have been adapted for use in urban areas (Smiley et al. 1991; Watson 1994; Kopinga and van den Burg 1995; Osmond and Platt 2000; Varlamoff et al. 2001; Struve 2002).

Adapting fertilization recommendations from other systems is convenient but of doubtful value for managing plant and soil nitrogen in urban environments. The goal of fertilizer use in agriculture is to maximize crop production and minimize the waste of plant nutrients (Ingestad 1977). Consequently, the factors influencing the selection, application, and fertilizer rate are the crop and soil characteristics, climate, yield, and cost of fertilizer in relation to sale price of the crop (Tisdale et al. 1985). In agriculture as opposed to arboriculture, however, some or the entire crop is removed annually. For example, as much as $65 \%$ to $75 \%$ of the total nitrogen uptake can be accounted for in the harvest of grain (Tisdale et al. 1985). Urban trees are more permanent and tend to adapt to the site while gradually acquiring soil nitrogen over many years. Despite these obvious contrasts, tree fertilization regimes have followed an agricultural mindset, with fertilization performed to attain rapid growth (Herms 1996). This view was promulgated in the belief that tree vitality was equated with fast growth and tree stress with slow growth (Miller 1998).

Urban tree fertilization practices are specified by the ANSI A300 standards for fertilization (American National Standards Institute 2001). Standard 7.2.1 states that the reason for fertilization is to "supply nutrients determined to be deficient to achieve a clearly defined objective, and this objective should be accomplished in the manner most beneficial to the plant." According to standard 7.2.6, soil and/or foliar analysis should be used to determine the need for fertilizer. Standard 8.1.2 states that in the absence of a soil and/or foliar analysis a 3:1:2 or 3:1:1 fertilizer ratio should be used, and these ratios should be adjusted based on local knowledge, plant age and/or condition of the plant, soil, and environmental conditions. Standard 8.1.4 states that slowrelease fertilizers should be applied at rates between 1,000 to

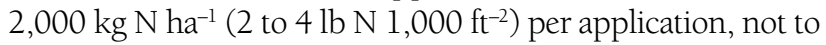

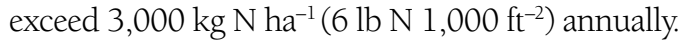

These recommendations fail to account for variables such as the soil nitrogen status or specific nitrogen requirements for plant species, physiology, phenology, or age. Maximum fertilizer efficiency is obtained if applied when the roots are acquiring nutrients; therefore, time of application is an important fertilization consideration (Rose 1999). For 
peach trees, $24 \%$ of the tree nitrogen is accumulated after leaf fall (Niederholzer et al. 2001). Approximately 50\%, (30 $\mathrm{kg} \mathrm{ha}^{-1}$ ) of foliar nitrogen is translocated to tree storage components, accounting for more than $80 \%$ of the nitrogen storage capacity of the tree. Consequently, foliar nitrogen resorption, even without fall fertilization, provides sufficient nitrogen from storage components to initiate normal growth in the spring until roots are able to access plant-available forms of soil nitrogen (Niederholzer et al. 2001).

Tree nutritional requirements vary with age. Nitrogen fertilization was unnecessary for establishment during the first growing season in microirrigated citrus, and only low rates of nitrogen $\left(<68 \mathrm{~g} \mathrm{tree}^{-1}\right.$ year $\left.^{-1}\right)$ were needed during the second growing season to maintain adequate tree nitrogen reserves (Weinert et al. 2002). Current tree care recommendations suggest limiting fertilization during the period when trees are being established (Khatamian et al. 1984; Marion 2000; Siewert et al. 2000).

Soil and foliar nitrogen analysis is suggested but not required according to ANSI standard 8.1.2 (American National Standards Institute 2001). This situation results in fertilizer being routinely applied without knowledge of extant soil nitrogen conditions (Beverly et al. 1997; Osmond and Platt 2000). Overapplication of fertilizer can be costly and may result in groundwater contamination or reductions in insect, disease, and stress resistance of landscape plants (Latimer et al. 1996; Rose and Biernacka 1999; Marion 2000; Siewert et al. 2000; Herms 2001; Smiley et al. 2002a, 2002b; Smith et al. 2002).

Recently, Plant Health Care (PHC) and Integrated Pest Management (IPM) programs have promoted site-specific prescription fertilization for the maintenance of urban trees (Smith et al. 2002). The ANSI standards serve as the foundation for prescription urban landscape fertilization, but their utility and value could be increased if they were expanded to address specific plant nitrogen demand and soil nitrogen supply in an array of urban environments.

\section{NITROGEN EVALUATION METHODS}

For prescription fertilization standards to be site-specific, nitrogen evaluation methods need to be developed or refined for use in urban environments. Nitrogen diagnostic methods need to be both practical and accurate if they are to be used by arborists and urban landscape managers to assess nitrogen status and prior to prescription fertilization recommendations. Practical nitrogen assessments are affordable, convenient, and easily interpretable. Accurate nitrogen assessments are well correlated with soil nitrogen availability and plant nitrogen acquisition. Many methods of assessing soil nitrogen availability and plant acquisition of nitrogen have been developed or adapted from other systems. The accuracy and practicality of some common plant and soil nitrogen assessment methods are discussed (Tables 1 and 2).

\section{PLANT DIAGNOSTIC METHODS}

Plant assessments relate information about levels of nitrogen that the plant has acquired. Plant assessments do not reveal information about current or future plant nitrogen availability. Two plant assessments are reviewed that are used to assess site nitrogen status.

\section{Visual Plant Assessment}

Visual plant assessments may be performed by examining attributes such as leaf size, shape, and color. Visual assessments of foliage are performed on site without the need for specialized equipment; therefore, they provide quick and easy information about plant nitrogen status. Typical symptoms associated with nitrogen deficiencies include uniform chlorosis starting in the older leaves, reduced size and abundance of leaves, and reduced shoot growth (Kozlowski 1985; Perry and Hickman 1998). Leaf color deficiency symptoms fluctuate in response to nutrient availability and typically occur because a plant cannot adjust quickly enough to a newly decreased nutrient supply

Table 1. Commonly performed plant nitrogen assessments and their advantages, disadvantages, and associated cost.

\begin{tabular}{llll}
\hline $\begin{array}{l}\text { Plant nitrogen } \\
\text { assessment/foliar }\end{array}$ & Advantages & Disadvantages & Cost of analysis* \\
\hline Visual assessment & In-field measurement & Does not directly measure acquisition & Unnecessary \\
& & Does not measure availability & \\
& Subjective & \\
& Environmental variation & \\
& Precludes preventive management &
\end{tabular}

\begin{tabular}{|c|c|c|c|}
\hline Nitrogen analysis & Measures plant acquisition & $\begin{array}{l}\text { Does not measure availability } \\
\text { Environmental variation } \\
\text { Insufficient comparative data }\end{array}$ & $\begin{array}{l}\text { Range: } \$ 9 \text { to } \$ 17 \\
\text { Mean: } \$ 8\end{array}$ \\
\hline
\end{tabular}

\footnotetext{
*Cost estimates (U.S. dollars) are rounded to nearest whole dollar $(n=3)$. Midwest Laboratories, Inc. 13611 B Street Omaha, NE 68144-3693. University of Idaho Analytical Sciences Laboratories, Holm Research Center, Moscow, ID 83843-2203. Servi-Tech Laboratories, Inc., 1602 Park West Drive, P.O. Box 169, Hastings, NE 6890-0169.
} 
Table 2. Commonly performed soil nitrogen assessments and their advantages, disadvantages, and associated costs.

\begin{tabular}{ll}
$\begin{array}{l}\text { Soil nitrogen } \\
\text { assessment }\end{array}$ & Advantages \\
\hline $\begin{array}{l}\text { Substrate carbon:nitrogen } \\
\text { ratios }\end{array}$ & May relate potential availability \\
Total soil nitrogen & May relate potential availability \\
Organic nitrogen & $\begin{array}{l}\text { May relate potential availability } \\
\text { Represents current availability }\end{array}$ \\
Mineral nitrogen & Represents current availability
\end{tabular}

Potential nitrogen

mineralization

Microbial biomass and

activity

Total soil organic matter

Particulate organic matter**
Measure of potential availability

Measure of potential availability

May represent potential availability Indicator of overall soil quality

May represent potential availability

Represents active organic matter Indicator of overall soil quality

$\begin{array}{ll}\text { Disadvantages } & \text { Cost of analysis* } \\ \text { Does not measure acquisition } & \text { Range: } \$ 10 \text { to } \$ 16 \\ \text { Impractical due to litter removal } & \text { Mean: } \$ 12\end{array}$

Does not measure acquisition Overestimate of availability

Range: $\$ 10$ to $\$ 16$

Mean: $\$ 14$

Does not measure acquisition

May not relate potential availability

Unavailable

Does not measure acquisition

Does not relate potential availability

Range: $\$ 11$ to $\$ 19$

Mean: $\$ 14$

Environmental variation

Includes microbial availability

Does not measure acquisition

Artificial laboratory conditions

Unavailable

Does not measure acquisition

Environmental variation

Unavailable

Does not measure acquisition

Includes recalcitrant organic matter

Range: $\$ 4$ to $\$ 11$

Mean: $\$ 7$

Does not measure acquisition

Range: $\$ 4$ to $\$ 11$

Mean: $\$ 7$

*Cost estimates (U.S. dollars) are rounded to nearest whole dollar $(n=3)$. Midwest Laboratories, Inc., 13611 B Street Omaha, NE 68144-3693. University of Idaho Analytical Sciences Laboratories, Holm Research Center, Moscow, ID 83843-2203. Servi-Tech Laboratories, Inc., 1602 Park West Drive, P.O. Box 169, Hastings, NE 6890-0169.

**POM isolated by particle size fractionation method.

(Ingestad and Lund 1979). As trees grow, internal nutrients are diluted unless the nutrient supply is augmented by increased absorbing root volume (roots growing into new soil), increased soil nutrients exchangeability (alteration of cation exchange capacity), or increased soil nutrient availability (organic matter, fertilization, change in $\mathrm{pH}$, etc.). Leaf color change is not an exclusive symptom of a soil nitrogen deficiency; it may also be symptomatic of reduced plant nutrient uptake caused by root diseases, girdling roots, drought, adverse soil temperatures, compaction, waterlogged soils, nematodes, herbicides, and salt injury (Perry and Hickman 1998; Harris et al. 2004). Visual symptoms are delayed, and leaves often remain green while the plant experiences a reduction in growth (Ingestad and Lund 1979). Therefore, diagnosis with visual plant assessments preclude management options to prevent nitrogen deficiencies. The quality of visual plant assessments is limited by interpretation and subjectivity, and they fail to reveal information about future soil nitrogen available for plant acquisition (Kozlowski 1985). Reliance on visual plant symptoms alone to diagnose plant nitrogen acquisition and soil nitrogen availability is inadequate to determine the actual nitrogen status of the plant and its environment (Perry and Hickman 1998).

\section{Foliar Nitrogen}

Foliar nitrogen analysis provides a quantitative assessment of leaf nitrogen concentration. Foliar nitrogen measurements require laboratory analysis and were found to be moderately subjective by a survey of soil and plant analysis laboratories in the United States (Table 1). Measurements of foliar nitrogen can reveal information about the nitrogen acquired, translocated, and used for physiological processes (Poorter and Bergkotte 1990; Wood et al. 1992; Kopinga and van den Burg 1995; Cornelissen et al. 1997; Li et al. 1998; Perry and Hickman 1998). Foliar nitrogen analysis is preferred as a research tool because it indicates the amount that trees had acquired and translocated, rather than just the soil nitrogen that may or may not be available to trees (Kopinga and van den Burg 1995). Foliar nitrogen assessments provide an indication of current nitrogen availability, but they fail to reveal information about the future nitrogen 
availability of a site. In addition, foliar nitrogen assessments must take into account factors that can impact the foliar nitrogen concentrations, such as the environment, plant species, and age of the foliage and the plant (Cornelissen et al. 1997). Leaf nitrogen content varies throughout the season as the plant translocates nitrogen to meet changing source and sink demands; therefore, foliar nitrogen measurements must account for temporal changes (Hopkins 1999).

To be a viable tool for assessing nitrogen status, foliar nitrogen concentrations need to correlate with plant response to fertilization and soil nitrogen availability (Harris et al. 2004). Unfortunately, these relationships have yet to be adequately examined. While attempts have been made to ascertain foliar nitrogen levels of a variety of urban species, the database is still relatively deficient (Smith 1972; Kopinga and van den Burg 1995; Mills and Jones 1996; Perry and Hickman 1998, 1999). Perry and Hickman's (1999) survey of 25 landscape tree species to determine baseline leaf nitrogen information is limited for urban site nitrogen diagnosis because foliage was sampled between June and August only, trees were all within the same age class, and trees were grown in the same type of irrigated lawn environment. Mills and Jones (1996) report leaf nitrogen contents for 252 tree species, but many of the values are from nursery and container-grown trees and not urban environments. Foliar nitrogen analysis is limited as a diagnostic tool because of a lack of comparative data representing the diversity of urban tree species, ages, and phenology, and the unpredictable environments in which they are grown. Without the interpretative aid of an adequate database, arborists are forced to use general guidelines, such as "trees in good health often have higher concentrations of nitrogen when young than when mature" (Binns et al. 1983).

\section{SOIL DIAGNOSTIC METHODS}

Soil nitrogen analyses can be used to measure the current nitrogen available for plant uptake as well as the amount that will potentially be available at some time in the future. Although direct assessment of plant acquisition with these measurements is impossible, they can provide valuable information regarding soil nitrogen availability and the potential nitrogen acquisition by plants. Many of the soil chemical and biological measurements that have been proposed to assess soil nitrogen status will be reviewed.

\section{Substrate Carbon-to-Nitrogen Ratios}

Litter quality has been used to assess site nitrogen status. These measurements require expensive laboratory analysis (Table 2). The carbon:nitrogen ratio (C:N) of plant litter impacts the rates of microbial decomposition and nitrogen mineralization (Aber and Melillo 1980; Seneviratne et al. 1999), but litter C:N is an inconsistent predictor of the direct decomposition kinetics that determine nitrogen availability (Aber et al. 1993; Recous et al. 1995; Pare et al. 1998; Senevirante et al. 1999). Consequently, modifications of the $\mathrm{C}: \mathrm{N}$ ratio, such as the lignin:nitrogen ratio, have been proposed to predict decomposition and nitrogen mineralization (Melillo et al. 1982; Gower and Son 1992; Stump and Binkley 1993; Scott and Binkley 1997). Litter quality impacts decomposition, but linkages between litter quality and available soil nitrogen are unsubstantiated (Scott and Binkley 1997). Furthermore, aboveground litter measurements do not include contributions to the soil organic matter pool from root turnover. Litter measurements are limited for use in urban systems due to litter removal for landscape aesthetic presentation. Consequently, using C:N and other litter measurements to predict available nitrogen in urban soils is impractical and possibly inaccurate.

\section{Total Soil Nitrogen}

Total soil nitrogen includes inorganic and organic forms that may be available or unavailable for plant uptake. Measurements of total soil nitrogen ranked among the most expensive nitrogen diagnostic methods surveyed (Table 2). As previously mentioned, a significant portion of the total soil nitrogen is present in forms associated with humic colloids, clay minerals, or microbial biomass and therefore is unavailable for plant acquisition (Mulvaney and Khan 2001). A measurement of total soil nitrogen includes unavailable forms; thus, the potential exists to significantly overestimate nitrogen available for plant uptake. Soils with variable nitrogen mineralization potentials exist with similar levels of total soil nitrogen (Magdoff 1991). Total soil nitrogen fails to correlate with available nitrogen because the percentage of organic nitrogen mineralized tends to decrease as total soil nitrogen increases. For these reasons, total soil nitrogen is an inaccurate measure of nitrogen availability (Drinkwater et al. 1996).

\section{Soil Organic Nitrogen}

Measurements of dissolved organic nitrogen have been proposed as indices of soil nitrogen availability (Khan et al. 2001; Mulvaney et al. 2001). The organic nitrogen fraction is typically greater than the mineral nitrogen pool (Nadelhoffer et al. 1985; Aber et al. 1993; Magill et al. 1997; Evangelou 1998; Jones and Kielland 2002). While organic nitrogen is generally considered unavailable to plants, recent studies have found that certain trees can attain some of their nitrogen in organic form (Nasholm et al. 1998; Jones and Kielland 2002). A nitrification block is thought to exist in these soils, reducing nitrate available for plant uptake and requiring plants to acquire nitrogen in organic form. Trees have been known to acquire nitrogen from urea fertilizer, which is an organic form of nitrogen (Harris et al. 2004). Consequently, the organic nitrogen pool is a potential contributor to the pool of soil nitrogen available for plant 
uptake (Chapin 1995; Raab et al. 1996; Lipson and Monson 1998; Jones and Kielland 2002). An organic nitrogen measurement has been used to identify cornfields that require nitrogen fertilization (Khan et al. 2001; Mulvaney et al. 2001), but others have suggested that organic nitrogen measurements are unreliable predictors of nitrogen availability (Keeney and Bremner 1964; Porter et al. 1964; Khan 1971; Smith and Young 1975; Meints and Peterson 1977; Tisdale and Oades 1982; Roberson et al. 1991; Drinkwater et al. 1996). Measurements of soil organic nitrogen were not available from the laboratories surveyed (Table 2); therefore, measurements of soil organic nitrogen are currently not practical for assessing nitrogen availability in urban ecosystems.

\section{Soil Mineral Nitrogen}

Measurements of the mineral nitrogen pool are often performed to identify the current soil nitrogen availability status, but reveal little information about the future soil nitrogen availability. Measurements of soil mineral nitrogen are inherently variable due to influential environmental factors such as moisture, temperature, and microbial activity (Khan et al. 2001; Mulvaney et al. 2001). Soil mineral nitrogen assessments are subject to seasonal variations and require interpretation and testing throughout the year (Khan et al. 2001). Because of inherent variability and environmental confounding, measurements of soil mineral nitrogen are routinely ignored for assessing nitrogen availability (Mader and Cook 1982). Mineral nitrogen measurements were found to be relatively expensive when compared to other nitrogen diagnostic measurements (Table 2).

\section{Total Soil Organic Matter}

Because of its role in nitrogen storage and release, soil organic matter is a critical determinant of overall soil quality and is often proposed as an index of soil nutrient status (Tisdale and Oades 1982; Burger and Pritchett 1984; Fox et al. 1986; Sikora and Stott 1996; McLaughlin et al. 2000) and nitrogen availability (McLaughlin et al. 2000; Ding et al. 2002). Soil organic matter measurements are relatively inexpensive and commonly offered by commercial soil testing laboratories (Table 2). Total soil organic matter changes are slow (Sikora and Stott 1996); thus, seasonal variations of soil nitrogen are difficult to predict with total soil organic matter assessments. Humification creates a recalcitrant component of soil organic matter that is part of the total organic matter but is typically inactive in decomposition and nitrogen mineralization (Chefetz et al. 2002; Graham et al. 2002). Recalcitrant organic matter fractions have been found to occupy as much as $60 \%$ to $70 \%$ of the total soil organic matter (Schnitzer 1986). Turnover rates of stable soil organic matter components have been estimated to occur over 1,500 years (Campbell 1978; Parton et al.
1987). Therefore, in-season or season-to-season dynamics in nitrogen availability would be difficult to detect with total soil organic matter measurements. Measurements of total soil organic matter by themselves are inadequate for providing sufficient information to assess nitrogen availability (Sikora and Stott 1996).

\section{Soil Microbial Biomass and Activity}

Measurements of microbial biomass and activity have been used to investigate nitrogen availability (Rice et al. 1996). Specialized laboratory analyses are required to examine microbial populations and products, but these measurements are rarely offered by commercial soil testing laboratories (Rice et al. 1996) (Table 2). Because the soil microbial biomass has a turnover time of 1 to 3 years, it responds quickly to conditions affecting soil organic matter (Jenkinson et al. 1980; Paul 1984; Schnurer et al. 1985). Consequently, microbial biomass and activity are likely to indicate changes in soil organic matter and nitrogen availability (Powlson et al. 1987; Bonde et al. 1988; Sparling 1992; Rice et al. 1996). Measurements of enzymes such as urease, amylase, and amidase were used to assess microbial populations (Stroo and Jencks 1982). That study found amylase activity to increase with age of soils in plantings of black locust (Robinia pseudoacacia) and to be highly correlated with organic matter accumulation, microbial respiration, and mineralizable nitrogen. Measurements of soil microbial biomass and activity are limited due to variability from factors that impact microbial populations, such as temperature and moisture (Insam et al. 1989; Van Gestel et al. 1992; Grayston et al. 2001), $\mathrm{CO}_{2}$ (Hu et al. 1999), pH, substrate, and nutrient availability (Joergensen and Scheu 1999; Jonasson et al. 1999; Schmidt et al. 2000; Nguyen and Guckert 2001; Savin et al. 2001), macrofauna trophic interactions (Jordan et al. 1999; Cole et al. 2002), compaction (Breland and Hansen 1996), root exudation (Grayston et al. 1996), and other disturbances (Setala et al. 2000; Wright and Coleman 2002).

\section{Soil Nitrogen Mineralization}

Estimates of nitrogen mineralization are used to investigate soil nitrogen availability (Stanford and Smith 1972; Keeney 1982; Molina et al. 1983; Drinkwater et al. 1996; Verchot et al. 2001; Anderson 2002; Picone et al. 2002) (Table 2). Soil nitrogen mineralization assessments measure the amount of nitrogen mineralized by microbial activity under both aerobic and anaerobic conditions. Incubations are performed under laboratory conditions, and potential nitrogen mineralization dynamics may differ from those in the field (Drinkwater et al. 1996). In situ measurements of nitrogen mineralization using anion exchange membranes have been used (Hart and Firestone 1991; Qian and Schoenau 1995), but field effects of moisture, temperature, substrate, 
microbial, and root activity create variation in nitrogen mineralization measurements (Liljeroth et al. 1990; Liljeroth et al. 1994). Additionally, in situ measurements need to be properly installed, and many measurements need to be taken because of environmental variability. Laboratory mineralization measurements are performed under constant and equal environmental conditions, which is desirable for diverse soil comparisons (Drinkwater et al. 1996). Unfortunately, measurements of potentially mineralizable nitrogen are rarely offered by commercial soil testing laboratories (Picone et al. 2002), and a practical method of assessing mineralizable nitrogen in the field or laboratory has yet to be developed for use in diverse urban soil environments.

Chemical methods that extract portions of the organic or mineral nitrogen pools are available (Schoenholtz et al. 2000), but they tend to be less accurate predictors of nitrogen availability than biological indices (Qafoku et al. 2001). Biological assessments are considered accurate measures of nitrogen availability because they simulate the activities of soil microorganisms and soil organic nitrogen to mineral nitrogen release (Keeney 1982; Drinkwater et al. 1996; Knoepp et al. 2000), but are not practical because they are rarely offered by commercial soil testing laboratories (Picone et al. 2002). Therefore, if a practical nitrogen diagnostic method that is well correlated with soil biological indices could be identified, arborists and urban landscape managers could use this method to diagnose nitrogen status of an urban site.

\section{Particulate Soil Organic Matter}

Measurements of active soil organic matter components have been found to relate soil nitrogen status (Parton et al. 1987; Janzen et al. 1992; Cambardella and Elliott 1992, 1993; Biederbeck et al. 1994; Magid et al. 1996; Chan 1997; Janzen et al. 1998; Six et al. 1998). An active soil organic matter component was first suggested by Gainey (1936) and first quantified with the use of ${ }^{15} \mathrm{~N}$ and kinetic analysis by Jansson (1958). Campbell (1978) identified compartments of stable and labile organic matter with characteristic turnover rates of 53 and 1,429 years, respectively. Paul and Juma (1981) revised existing soil organic models by suggesting that the active portion be separated into biomass and nonbiomass components. Current soil organic matter models include two or three organic matter pools with different turnover rates (Parton et al. 1987; Paustian et al. 1992; Cambardella and Elliott 1992). For example, Parton et al. (1987) proposed a model with three soil organic matter (SOM) fractions: an active SOM fraction of microbes and microbial products with a turnover time of 1 to 5 years; a slow SOM pool with a turnover time of 20 to 40 years; and, a passive SOM pool with a turnover time of 200 to 1,500 years.

Recent studies have found that changes in the total soil organic matter are primarily in the particulate organic matter (POM) fractions (Parton et al. 1987; Elliott and
Cambardella 1991; Janzen et al. 1992; Cambardella and Elliott 1992,1993; Biederbeck et al. 1994; Cambardella and Elliott 1994; Bremer et al. 1994; Magid et al. 1996; Chan 1997; Janzen et al. 1998; Six et al. 1998). Particulate organic matter is relatively labile and represents a portion of the organic matter pool that is actively involved in decomposition. The POM accumulated from organic inputs is a direct source for the growth and activity of soil microorganisms (Gale and Cambardella 2000; Franzluebbers and Stuedemann 2003). In tropical systems, POM accounts for $31 \%$ to $67 \%$ of the total soil organic matter nitrogen and carbon variability (Duriancik 2001) and as much as 50\% of the total soil organic matter in cold and semiarid climates (Franzluebbers and Arshad 1997; Chan 1997). Particulate organic matter nitrogen is positively correlated with soil microbial nitrogen, and potentially mineralizable nitrogen (Alvarez et al. 1998; Sohn Lopez-Forment 2000; Duriancik 2001; Stinner et al. 2003; Franzluebbers and Stuedemann 2003). Consequently, examinations of POM fractions potentially indicate changes in soil organic matter and nitrogen availability (Paul 1984; Powlson et al. 1987; Cambardella and Elliott 1992; Paustian et al. 1992; Gregorich et al. 1994; Magid et al. 1996; Chan 1997; Alvarez et al. 1998; Janzen et al. 1998; Graham et al. 2002; Franzluebbers and Stuedemann 2003; Salas et al. 2003).

Particulate organic matter measurements are performed by isolating soil organic matter portions with density and particle size separations. Models of POM dynamics were developed to distinguish occluded and free organic matter (Van Veen and Paul 1981; Cambardella and Elliott 1992; Christensen 1996; Elliott et al. 1996). It has been suggested that free organic matter is found between soil aggregates and is readily accessible for decomposition (Cambardella and Elliott 1992; Six et al. 1998). Occluded organic matter is less accessible for microbial decomposition because it is aggregated within soil aggregates. Soil density fractionation methods have been used to isolate free POM fractions of plant residues physically unprotected by soil aggregates (Spycher et al. 1983; Janzen 1987; Christensen 1992; Janzen et al. 1992; Boone 1994; Barrios et al. 1997). Density fractionation involves suspending POM in a solution of known specific gravity, such as NaI $(S G=1.70)$, separating the floating light fraction from the sinking heavy fraction, and washing them with $\mathrm{CaCl}_{2}$ (Janzen et al. 1992).

The light fraction is considered highly labile and responsive to management changes, but its importance as a nitrogen source is disputed (Janzen 1987; Janzen et al. 1992; Bierderbeck et al. 1994; Boone 1994; Curtin and Wen 1999). Boone (1994) found that the light fraction contributed only $2 \%$ to $13 \%$ of the total soil nitrogen mineralization potential, but the heavy fraction was found to be the primary nitrogen source. Janzen et al. (1992) found that the light fraction was significantly correlated with microbial nitrogen 
and respiration, but the high $\mathrm{C}: \mathrm{N}$ ratio of the light fraction induced temporary nitrogen immobilization and a less consistent relationship with potential nitrogen mineralization. Furthermore, Barrios et al. (1997) found that available nitrogen can be accurately predicted with a simplified density fractionation method of combining the light $\left(<1.13 \mathrm{Mg} \mathrm{m}^{-3}\right)$ and intermediate fractions $\left(<1.37 \mathrm{Mg} \mathrm{m}^{-3}\right)$.

Particle size separations of POM isolate soil organic matter between 2.0 and $0.053 \mathrm{~mm}$ in diameter (Cambardella and Elliott 1992, 1993; Magid et al. 1996; Six et al. 1998; Gill et al. 1999; Bayer et al. 2001; Kettler et al. 2001; Stone et al. 2001; Six et al. 2002; Stinner et al. 2002; Salas et al. 2003). Particulate organic matter particle size separations include both the heavy- and light-fraction organic matter because they do not isolate physically protected from nonphysically protected soil organic matter (Parton et al. 1987). Particulate organic matter by particle size separation isolates an intermediately available organic matter pool. Particle size fractionations of POM are easily performed by soil dispersion and wet sieving (Parton et al 1987;

Cambardella and Elliott 1992; Paustian et al. 1992; Cambardella and Elliott 1993; Six et al. 1998; Curtin and Wen 1999; Bayer et al. 2001; Ding et al. 2002). Soil organic matter, carbon, or nitrogen contents in the POM fraction can then be determined by methods such as loss on ignition and automated dry combustion (Table 2). Particulate organic matter has the potential to relate soil nitrogen availability throughout the growing season, without being overly sensitive to in-season environmental perturbations (Franzluebbers and Stuedemann 2003). For these reasons, POM particle-size separations may be a practical and accurate assessment of soil nitrogen availability throughout the growing season in diverse urban sites.

\section{TOWARD IMPROVED URBAN TREE NITROGEN MANAGEMENT}

To improve existing standards for determining nitrogen status and needs of woody landscape plants, soil and plant assessment techniques must be improved and correlated with soil nitrogen supply and plant nitrogen demand to be documented (Harris et al. 2004). The selection of an appropriate diagnostic method to assess site nitrogen status is difficult. Prescribing a fertilization treatment without investigating the soil and plant nitrogen status is currently acceptable (American National Standards Institute 2001). As a result, diagnosis prior to prescription is sometimes lacking. An increase in fertilization technology has greatly outpaced plant and site nitrogen diagnostic techniques (Tisdale et al. 1985).

The need for independent plant and site nitrogen assessments is critical due to the diversity of individual site characteristics in urban areas. Because of the innate variability in urban plants and soil characteristics, the value of a nitrogen diagnostic tool is dependent on its ability to accurately predict nitrogen availability across extreme variation in environments. Of the nitrogen diagnostic techniques mentioned, POM measurements have potential to be practical methods of accurately estimating the nitrogen availability in urban landscapes.

Investigations of soil nitrogen pools, organic matter quantity and quality, as well as soil microbial populations will help urban landscape managers' account for dynamic processes that determine soil nitrogen availability in urban soils. Increased awareness of soil nitrogen cycling and plant acquisition will enable landscape managers to refine nitrogen diagnoses and fertilization prescriptions for urban vegetation. The development of comprehensive diagnostic methods are required to begin building the baseline of information regarding soil organic matter cycling, microbial processes, nitrogen availability and plant health in urban environments.

\section{LITERATURE CITED}

Aber, J.D. 1992. Nitrogen cycling and nitrogen saturation in temperate forest ecosystems. Trends Ecol. Evol. 7:220223.

Aber, J.D., and J.D. Melillo. 1980. Litter decomposition: Measuring relative contributions of organic matter and nitrogen to forest soils. Can. J. Bot. 58:416-421.

Aber, J.D., A.H. Magill, R. Boone, J.M. Melillo, P. Steudler, and R. Bowden. 1993. Plant and soil responses to chronic nitrogen additions at the Harvard Forest, Massachusetts. Ecol. Appl. 3:156-166.

Alvarez, C.R., R. Alvarez, M.S. Grigera, and R.S. Lavado. 1998. Associations between organic matter fractions and the active soil microbial biomass. Soil Biol. Biochem. 30:767-773.

Anderson, S. 2002. The relationship between nutrients and other elements to plant diseases. Tree Care Ind. March 2002:26-32.

American National Standards Institute. 1995. American National Standard for Tree Care Operations-Tree, Shrub and Other Woody Plant Maintenance Standard Practices (Fertilization). American National Standards Institute, New York, NY. 15 pp.

Anttonen, S., R. Piispanen, J. Ovaska, P. Mutikainen, P. Saranpaa, and E. Vapaavuori. 2002. Effects of defoliation on growth, biomass allocation, and wood properties of Betula pendula clones grown at different nutrient levels. Can. J. For. Res. 32:498-508.

Barrios, E., F. Kwesiga, R.J. Buresh, and J.I. Sprent. 1997. Light fraction soil organic matter and available nitrogen following trees and maize. Soil Sci. Soc. Am. J. 61:826-831.

Bayer, C., L. Martin-Neto, J. Mielniczuk, C.N. Pillon, and L. Sangoi. 2001. Changes in soil organic matter fractions under subtropical no-till cropping systems. Soil Sci. Soc. Am. J. 65:1473-1478. 
Beverly, R.B., W. Florkowski, and J.M. Ruter. 1997. Fertilizer management by landscape maintenance and lawn care firms in Atlanta. HortTechnology 7:442-445.

Beyer, L., H.-P. Blume, D.-C. Elsner, and A. Willnow. 1995. Soil organic matter composition and microbial activity in urban soils. Sci. Tot. Environ. 168:267-278.

Biederbeck, V.O., H.H. Janzen, C.A. Campbell, and R.P. Zenter. 1994. Labile organic matter as influenced by cropping practices in an arid environment. Soil Biol. Biochem. 12:1647-1656.

Binns, W.O., H. Insley, and J.B.H. Gardiner. 1983. Nutrition of broadleaved amenity trees: I. Foliar sampling and analysis for determining nutrient status. Arboric. Res. Note. 50/83/555:1-4.

Bondada, B.R., J.P. Syvertson, and L.G. Albrigo. 2001. Urea nitrogen uptake by citrus leaves. HortScience 36:10611065.

Bonde, T.A., J. Schnurer, and T. Rosswall. 1988. Microbial biomass as a fraction of potentially mineralizable nitrogen in soils from long-term field experiments. Soil Biol. Biochem. 20:447-452.

Boone, R.D. 1994. Light-fraction soil organic matter: origin and contribution to net $\mathrm{N}$ mineralization. Soil Biol. Biochem. 26:1459-1468.

Breland, T.A., and S. Hansen. 1996. Nitrogen mineralization and microbial biomass as affected by soil compaction. Soil Biol. Biochem. 28:655-663.

Broschat, T.K., and K.A. Klock-Moore. 2000. Root and shoot growth response to phosphate fertilization in containergrown plants. HortTechnology. 10:765-767.

Bullock, P., and P.J. Gregory. 1991. Soils: A neglected resource in urban areas. In Bullock, P., and P.J. Gregory (Eds.). Soils in the Urban Environment. Blackwell Scientific Publications, Cambridge, MA.

Burger, J.A., and W.L. Pritchett. 1984. Effects of clearfelling and site preparation on nitrogen mineralization in a southern pine stand. Soil Sci. Soc. Am. J. 48:1432-1437.

Burgess, M.S., G.R. Mehuys, and C.A. Madramootoo. 2002. Nitrogen dynamics of decomposing corn residue components under three tillage systems. Soil Sci. Soc. Am. J. 66:1350-1358.

Cabrera, R.I., and D.R. Devereaux. 1999. Crapemyrtle posttransplant growth as affected by nitrogen nutrition during nursery production. J. Am. Hortic. Sci. Soc. 124:94-98.

Cambardella, C.A., and E.T. Elliott. 1992. Particulate soil organic matter changes across a grassland cultivation sequence. Soil Sci. Soc. Am. J. 56:777-783.

_. 1993. Carbon and nitrogen distribution in aggregates from cultivated and native grassland soils. Soil Sci. Soc. Am. J. 57:1071-1076.
1994. Carbon and nitrogen dynamics of soil organic matter fractions from cultivated grassland soils. Soil Sci. Soc. Am. J. 58:123-130.

Campbell, C.A. 1978. Soil organic carbon, nitrogen, and fertility, pp 173-272. In Schnitzer, M., and S.U. Khan (Eds.). Soil Organic Matter. Elsevier Scientific, Amsterdam, The Netherlands.

Chan, K.Y. 1997. Consequences of changes in particulate organic carbon in vertisols under pasture and cropping. Soil Sci. Soc. Am. J. 61:1382-1386.

Chapin, F.S. 1995. New cog in the nitrogen cycle. Nature 377:199-200.

Chefetz, B., J. Tarchitzky, A.P. Deshmukh, P.G. Hatcher, and Y. Chen. 2002. Structural characterization of soil organic matter and humic acids in particle-size fractions of an agricultural soil. Soil Sci. Soc. Am. J. 66:12-141.

Christensen, B.T. 1992. Physical fractionation of soil and organic matter in primary particle size and density separates. Adv. Soil Sci. 20:1-90.

_ 1996. Matching measurable soil organic matter fractions with conceptual pools in simulation models of carbon turnover: Revision of soil structure. pp 143-159. In Powlson, D.S., et al. (Eds.). Evaluation of Soil Organic Models. NATO ASI Series, Vol. 138. Springer-Verlag, Berlin/Heidelberg, Germany.

Clinton, P.W., R.B. Allen, and M.R. Davis. 2002. Nitrogen storage and availability during stand development in a New Zealand Nothofagus forest. Can. J. For. Res. 32:344-352.

Cole, D.W. 1995. Soil nutrient supply in natural and managed forests. Plant Soil. 168-169:43-53.

Cole, L., R.D. Bardgett, P. Ineson, and P.J. Hobbs. 2002. Enchytraeid worm (oligochaeta) influences on microbial community structure, nutrient dynamics and plant growth in blanket peat subjected to warming. Soil Biol. Biochem. 34:83-92.

Cornelissen, J.H.C., M.J.A. Werger, P. Castro-Diez, J.W.A. van Rheenen, and A.P. Rowland. 1997. Foliar nutrients in relation to growth, allocation and leaf traits in seedlings of a wide range of woody plant species and types. Oecologia 111:460-469.

Craul, P.J. 1985. A description of urban soils and their desired characteristics. J. Arboric. 11:330-339.

- 1993. Urban soils: An overview and their future. In Watson, G.W., and D. Neely, (Eds.). The Landscape Below Ground. Proceedings of an International Workshop on Tree Root Development in Urban Soils. International Society of Arboriculture, Champaign, IL.

-J. 1999. Urban Soils: Applications and Practices. John Wiley and Sons, New York, NY.

Curtin, D., and G. Wen. 1999. Organic matter fractions contributing to soil nitrogen mineralization potential. Soil Sci. Soc. Am. J. 63:410-415. 
Ding, G., J.M. Novak, D. Amarasiriwardena, P.G. Hunt, and B. Xing. 2002. Soil organic matter characteristics as affected by tillage management. Soil Sci. Soc. Am. J. 66:421-429.

Drinkwater, L.E., C.A. Cambardella, J. Reeder, and C.W. Rice. 1996. Potentially mineralizable nitrogen as an indicator of biologically active soil nitrogen, pp 217-229. In Doran, J.W., and A.J. Jones (Eds.). Methods for Assessing Soil Quality. Soil Science Society of America, Madison, WI.

Elliott, E.T., and C.A. Cambardella. 1991. Physical separation of soil organic matter. Agric. Ecosyst. Environ. 34:407-419.

Elliott, E.T., K. Paustian, S.D. Frey. 1996. Modeling the measurable or measuring the modelable: A hierarchical approach to isolating meaningful soil organic matter fractions, pp 161-179. In Powlson, D.S., et al. (Eds.). Evaluation of Soil Organic Models. NATO ASI Series, Vol. 138, Springer-Verlag, Berlin/Heidelberg, Germany.

Ericsson, T., L. Rytter, and E. Vapaavuor. 1996. Physiology of carbon allocation in trees. Biom. Bioener. 11:115-127.

Evangelou, V.P. 1998. Environmental Soil and Water Chemistry Principles and Applications. John Wiley and Sons, New York, NY.

Fenton, T.E., and M.E. Collins. 2000. The soil resource and its inventory. In Brown, R.B., J.H. Huddleston, and, J.L. Anderson (Eds.). Managing Soils in an Urban Environment. American Society of Agronomy, Madison, WI.

Fox, T.R., J.A. Burger, and R.H. Kreh. 1986. Effects of site preparation on nitrogen dynamics in the southern Piedmont. For. Ecol. Manage. 15:241-256.

Franzluebbers, A.J., and M.A. Arshad. 1997. Particulate organic carbon content and potential mineralization as affected by tillage and texture. Soil Sci. Soc. Am. J. 61:1382-1386.

Franzluebbers, A.J., and J.A. Stuedemann. 2003.

Bermudagrass management in the southern piedmont USA. III. Particulate and biologically active soil carbon. Soil Sci. Soc. Am. J. 67:132-138.

Gainey, P.L. 1936. Total nitrogen as a factor influencing nitrate accumulation in solids. Science 42:157-163.

Gale, W.J., and C.A. Cambardella. 2000. Carbon dynamics of surface residue- and root-derived organic matter under simulated no-till. Soil Sci. Soc. Am. J. 64:190-195.

Gerhold, H. 2002. Our heritage of community trees. Part 2. Arborist News June:31-33.

Gill, R., I.C. Burke, D.G. Milchunas, and W.K. Lauenroth. 1999. Relationship between root biomass and soil organic matter pools in the shortgrass steppe of eastern Colorado. Ecosystems 2:226-236.

Goldman, M.B., P.M. Groffman, R.V. Pouyat, M.J. McDonnell, and T.A. Pickett. 1995. $\mathrm{CH}_{4}$ uptake and $\mathrm{N}$ availability in forest soils along an urban to rural gradient. Soil Biol. Biochem. 27(3):281-286.

Gower, S.T., and Y. Son. 1992. Differences in soil and leaf litterfall nitrogen dynamics of five forest plantations. Soil Sci. Soc. Am. J. 56:1959-1966.
Graham, M.H., R.J. Haynes, and J.H. Meyer. 2002. Soil organic matter content and quality: Effects of fertilizer applications, burning and trash retention on a long-term sugarcane experiment in South Africa. Soil Biol. Biochem. 34:93-102.

Grayston, S.J., D. Vaughan, and D. Jones. 1996. Rhizosphere carbon flow in trees, in comparison with annual plants: The importance of root exudation and its impact on microbial activity an nutrient availability. Appl. Soil Ecol. 5:29-56.

Grayston, S.J., G.S. Griffith, J.L. Mawdsley, C.D. Campbell, and R.D. Bardgett. 2001. Accounting for variability in soil microbial communities of temperate upland grassland ecosystems. Soil Biol. Biochem. 33:533-551.

Gregorich, E.G., M.R. Carter, D.A. Anger, C.M. Monreal, and B.H. Ellert. 1994. Towards a minimum data set to assess soil organic matter quality in agricultural soils. Can. J. Soil Sci. 74:367-385.

Hairston, N.G., F.E. Smith, and L.B. Slobodkin. 1960. Community structure, population control, and competition. Am. Nat. 94:42-425.

Hangs, R.D., J.D. Knight, and C.J. Van Rees. 2003. Nitrogen accumulation by conifer seedlings and competitor species from 15nitrogen-labeled controlled-release fertilizer. Soil Sci. Soc. Am. J. 67:300-308.

Harris, R.W. 1992. Root-shoot ratios. J. Arboric. 18:39-42.

Harris, R.W., J.R. Clark, and N.P. Matheny. 2004. Arboriculture: Integrated Management of Landscape Trees, Shrubs, and Vines (4th ed.). Prentice Hall, Upper Saddle River, NJ.

Hart, S.C., and M.K. Firestone. 1991. Forest floor-mineral soil interactions in the internal nitrogen cycle of an oldgrowth forest. Biogeochemistry 12:103-127.

Herms, D.A. 1996. Growing, growing, gone. Am Nurseryman 184(2):52-58.

- 2001. The resource allocation trade-off. Arborist News October:41-47.

Herms, D.A., and W.J. Mattson. 1992. The dilemma of plants: To grow or defend. Q. Rev. Biol. 67(3):283-335.

Herms, D.A., J.E. Lloyd, and B.R. Stinner. 2002. Effects of organic mulches and fertilization on soil microbial activity, nutrient availability, and growth of river birch. Proceedings, International Symposium on Composting and Compost Utilization, 6-8 May 2002, Columbus, OH.

Hinesley, L.E., L.K. Snelling, C.R. Campbell, D.K. Roten, and J. Hartzog. 2000. Nitrogen increases fresh weight and retail value of fraser fir Christmas trees. HortScience 35:860-862.

Hopkins, W.G. 1999. Introduction to Plant Physiology. John Wiley and Sons, New York, NY

Hu, S., M.K. Firestone, and F.S. Chapin, III. 1999. Soil microbial feedbacks to atmospheric $\mathrm{CO}_{2}$ enrichment. Tree 14:433-437. 
Huinink, J.Th.M. 1998. Soil quality requirements for use in urban environments. Soil Till. Res. 47:157-162.

Hutchinson, G.E. 1959. Homage to Santa Rosalia, or why are there so many kinds of animals? Am. Nat. 93:145-159.

Ingestad, T. 1977. Nitrogen and plant growth; maximum efficiency of nitrogen fertilizers. AMBIO 6:146-151.

Ingestad, T., and A.-B. Lund. 1979. Nitrogen stress in birch seedlings. I. Growth technique and growth. Physiol. Plant 45:137-148.

Insam, H., D. Parkinson, and K.H. Domsch. 1989. Influence of macroclimate on soil microbial biomass. Soil Biol. Biochem. 21:211-221.

Jaffe, D.A. 1992. The nitrogen cycle, pp 263-284. In Butcher, S.S., R.J. Charlson, G.H. Orians, and G.V. Wolfe (Eds.). Global Biogeochemical Cycles. Academic Press, New York, NY.

Jansson, S.L. 1958. Tracer studies on nitrogen transformation in soil with special attention to mineralization-immobilization relationships. Ann. Royal Agric. Coll., Sweden 24:101-361.

Janzen, H.H. 1987. Soil organic matter characteristics after long-term cropping to various spring wheat rotations. Can. J. Soil Sci. 67:845-856.

Janzen, H.H., C.A. Campbell, S.A. Brandt, G.P. Lafond, and L. Townley-Smith. 1992. Light-fraction organic matter in soils from long-term rotations. Soil Sci. Soc. Am. J. 56:1799-1806.

Janzen, H.H., C.A. Campbell, R.C. Izaurralde, B.H. Ellert, N. Juma, W.B. McGill, and R.P. Zenter. 1998. Management effects on soil $C$ storage on the Canadian prairies. Soil Till. Res. 47:181-195.

Jenkinson, D.S., J.N. Ladd, and J.H. Rayner. 1980. Microbial biomass in soil-Measurement and turnover, pp 415471. In Paul, E.A., and J.N. Ladd (Eds.). Soil Biology and Biochemistry. Dekker, New York, NY.

Jenny, H. 1941. Factors of Soil Formation: A System of Quantitative Pedology. McGraw-Hill, New York, NY.

Joergensen, R.G., and S. Scheu. 1999. Response of soil microorganisms to the addition of carbon, nitrogen and phosphorous in forest Rendzina. Soil Biol. Biochem. 31:859-866.

Johnson, R.S., R. Rosecrance, S. Weinbaum, H. Andris, and J. Wang. 2001. Can we approach complete dependence on foliar-applied urea nitrogen in an early-maturing peach? J. Am. Hortic. Sci. 126:354-370.

Jonasson, S., A. Michelsen, I.K. Schmidt, and E.V. Neilsen. 1999. Responses in microbes and plants to changed temperature, nutrient, and light regimes in the Arctic. Ecology 80:1828-1843.

Jones, D.L., and K. Kielland. 2002. Soil amino acid turnover dominates the nitrogen flux in permafrost-dominated taiga forest soils. Soil Biol. Biochem. 34:209-219.

Jordan, D., F. Li, F. Ponder Jr., E.C. Berry, V.C. Hubbard, and K.Y. Kim. 1999. The effects of forest practices on earthworm populations and soil microbial biomass in a hardwood forest in Missouri. Appl. Soil Ecol. 13:31-38.

Keeney, D.R. 1982. Nitrogen availability indices. In Page, A.L. (Ed.). Methods of Soil Analysis. Part 2 (2nd ed.). Agron. Monogr. 9. ASA and SSSA, Madison, WI.

Keeney, D.R., and J.M. Bremner. 1964. Effect of cultivation on the nitrogen distribution in soils. Soil Sci. Soc. Am. J. 61:936-942.

Kettler, T.A., J.W. Doran, and T.L. Gilbert. 2001. Simplified method for soil particle-size determination to accompany soil-quality analyses. Soil Sci. Soc. Am. J. 65:849-852.

Khan, S.A., R.L. Mulvaney, and R.G. Hoeft. 2001. A simple soil test for detecting sites that are nonresponsive to nitrogen fertilization. Soil Sci. Soc. Am. J. 65:1751-1760.

Khan, S.U. 1971. Nitrogen fractions in a gray wooded soil as influenced by long-term cropping systems and fertilizers. Can. J. Soil Sci. 51:431-437.

Khatamian, H.K., J.C. Pair, and R. Carrow. 1984. Effects of turf competition and fertilizer application on trunk diameter and nutrient composition of honeylocust. J. Arboric. 10:156-159.

Knoepp, J.D., D.C. Coleman, D.A. Crossley Jr., and J.S. Clark. 2000. Biological indices of soil quality: An ecosystem case study of their use. For. Ecol. Manage. 138:357-368.

Kopinga, J., and J. van den Burg. 1995. Using soil and foliar analysis to diagnose the nutritional status of urban trees. J. Arboric. 21:17-23.

Kozlowski, T.T. 1985. Tree growth in response to environmental stresses. J. Arboric. 11:97-111.

Kraimer, R.A., W.C. Lindermann, and E.A. Herrera. 2001. Distribution of $15 \mathrm{~N}$-labeled fertilizer applied to pecan: A case study. HortScience 36:308-312.

Kraus, H.T., S.L. Warren, and C.E. Anderson. 2002. Nitrogen form affects growth, mineral nutrient content, and root anatomy of cotoneaster and rudbeckia. HortScience 37:126-129.

Latimer, J.G., R. D. Oetting, P.A. Thomas, D.L. Olson, J.R. Allison, S.K. Braman, J.M. Ruter, R.B. Beverly, W. Florkowski, C.D. Robacker, J.T. Walker, M.P. Garber, O.M. Lindstrom, and W.G. Hudson. 1996. Reducing the pollution potential of pesticides and fertilizers in the environmental horticulture industry: I. Greenhouse, nursery, and sod production. Hort Technology 6:115-124.

Li, Y.C., A.K. Alva, D.V. Calvert, and M. Zhang. 1998. A rapid nondestructive technique to predict leaf nitrogen status of grapefruit tree with various nitrogen fertilization practices. Hort Technology 8:81-86.

Liljeroth, E., P. Kuikman, and J.A. Van Veen. 1994. Carbon translocation to the rhizosphere of maize and wheat and influence on the turnover of native soil organic matter at different soil nitrogen levels. Plant Soil 161:233-240. 
Liljeroth, E., J.A. Van Veen, and H.J. Miller. 1990. Assimilate translocation to the rhizosphere of two wheat cultivars and subsequent utilization by rhizosphere microorganisms at two soil nitrogen levels. Soil Biol. Biochem. 22:1015-1021.

Lipson, D.A., and R.K. Monson. 1998. Plan-microbe competition for soil amino acids in the alpine tundra: Effects of freeze-thaw and dry-rewet events. Oecologia 113:406-414.

Mader, D.L., and R.N. Cook. 1982. Soil fertility for urban trees, pp 4.1-4.28. In Craul, P.J (Ed.). Urban Forest Soils: A Reference Workbook. Syracuse, NY.

Magdoff, F. 1991. Understanding the Magdoff pre-sidedress nitrate test for corn. J. Prod. Agric. 4:297-305.

Magid, J., A. Gorissen, and K.E. Giller. 1996. In search of the elusive "active" fraction of soil organic matter: Three size-density fractionation methods for tracing the fate of homogeneously 14C-labelled plant materials. Soil Biol. Biochem. 28:89-99.

Magill, A.H., J.D. Aber, J.J. Hendricks, R.D. Bowden, P.A. Stuedler, and J.M. Melillo. 1997. Biogeochemical response of forest ecosystems to simulated chronic nitrogen deposition. Ecol. Appl. 7:402-415.

Marion, D.F. 2000. Tree fertilization in the 21st century. In Siewert, A., B. Rao, and D.F. Marion (Eds.). In Tree and Shrub Fertilization: Proceedings from an International Conference on Tree and Shrub Fertilization. 17-18 May 2000, Fairlawn, OH. International Society of Arboriculture, Champaign, IL.

McAlister, J.A., and V.R. Timmer. 1998. Nutrient enrichment of white spruce seedlings during nursery culture and initial plantation establishment. Tree Phys. 18:195-202.

McDonald, A.J.S., A. Ericsson, and T. Lohammar. 1986a. Dependence of starch storage on nutrient availability and photon flux density in small birch (Betula pendula Roth). Plant Cell Environ. 9:433-435.

McDonald, A.J.S., T. Lohammar, and A. Ericsson. 1986b. Growth response to step-decrease in nutrient availability in small birch (Betula pendula Roth). Plant Cell Environ. 9:427-432.

McLaughlin, J.W., M.R. Gale, M.F. Jurgensen, and C.C. Trettin. 2000. Soil organic matter and nitrogen cycling in response to harvesting, mechanical site preparation, and fertilization in a wetland with a mineral substrate. For. Ecol. Manage. 129:7-23.

Meints, V.W., and G.A. Peterson. 1977. The influence of cultivation on the distribution of nitrogen in soils of the Ustoll suborder. Soil Sci. 124:334-342.

Melillo, J.M., Aber, J.D., Muratore, J.F. 1982. Nitrogen and lignin control of hardwood leaf litter decomposition dynamics. Ecology 63:621-626.

Miller, R.W. 1998. Tree fertilization, science, myth and ethics. Arborist News Dec. 1998:26-27.
Millard, P., and M.F. Proe. 1992. Storage and internal cycling of nitrogen in relation to seasonal growth of Sitka spruce. Tree Phys. 10:33-43.

Mills, H.A., and J.B. Jones Jr. 1996. Plant Analysis Handbook II. MicroMacro Publishing, Athens, GA.

Molina, J.A.E., C.E. Clapp, M.J. Schafer, F.W. Chichester, and W.E. Larson. 1983. NCSOIL, a model of nitrogen and carbon transformations in soil: Description, calibration, and behavior. Soil Sci. Soc. Am. J. 47:85-91.

Mugasha, A.C., and D.J. Pluth. 1994. 15N-labelled urea fertilization of a tamarack/black spruce mixed stand on a drained minerotrophic peatland: $15 \mathrm{~N}$ in soil and tree uptake. For. Ecol. Manage. 68:339-351.

Mulvaney, R.L., and S.A. Khan. 2001. Diffusion methods to determine different forms of nitrogen in soil hydrolysates. Soil Sci. Soc. Am. J. 65:1284-1292.

Mulvaney, R.L., S.A. Khan, R.G. Hoeft, and H.M. Brown. 2001. A soil organic nitrogen fraction that reduces the need for nitrogen fertilization. Soil Sci. Soc. Am. J. 65:1164-1172.

Nadelhoffer, K.J., J.D. Aber, and J.M. Melillo. 1985. Fine roots, net primary production and soil nitrogen availability: a new hypothesis. Ecology 66:1377-1390.

Nasholm, T., A. Ekblad, A. Nordin, R. Giesler, M. Hogberg, and P. Hogberg. 1998. Boreal forest plants take up organic nitrogen. Nature 392:914-916.

Neilsen, D., P. Millard, G.H. Neilsen, and E.J. Hogue. 2001. Nitrogen uptake, efficiency of use, and partitioning for growth in young apple trees. J. Am. Soc. Hortic. Sci. 126:144-150.

Nguyen, C., and A. Guckert. 2001. Short-term utilisation of 14C-[u]glucose by soil microorganisms in relation to carbon availability. Soil Biol. Biochem. 33:53-60.

Niederholzer, F.J.A., T.M. DeJong, J.-L. Saenz, T.T. Muraoka, and S.A. Weinbaum. 2001. Effectiveness of fall versus spring soil fertilization of field-grown peach trees. J. Am. Soc. Hortic. Sci. 125:644-648.

Osmond, D.L., and J.L. Platt. 2000. Characterization of suburban nitrogen fertilizer and water use on residential turf in Cary, North Carolina. HortTechnology 10:320-325.

Palmer, J.P., and M.J. Chadwick. 1985. Factors affecting the accumulation of nitrogen in colliery spoil. J. Appl. Ecol. 22:249-257.

Pare, T., H. Dinel, M. Schnitzer, and S. Dumontet. 1998. Transformations of carbon and nitrogen during composting of animal manure and shredded paper. Biol. Fertil. Soils. 26:173-178.

Parton, W.J., D.S. Schimel, C.V. Cole, and D.S. Ojima. 1987. Analysis of factors controlling soil organic matter levels in great plains grasslands. Soil Sci. Soc. Am. J. 51:1173-1179.

Paul, E.A. 1984. Dynamics of organic matter in soils. Plant Soil 76:275-285. 
Paul, E.A., and F.E. Clark. 1989. Soil Microbiology and Biochemistry. Academic Press, Toronto, ON.

Paul, E.A., and N.G. Juma. 1981. Mineralization and immobilization of soil nitrogen by microorganisms, pp 179-204. In Clark, F.E., and T. Rosswall (Eds.). Terrestrial Nitrogen Cycles: Processes, Ecosystems Strategies and Management Impacts. Ecol. Bull. (Sweden) 33.

Paustian, K., W.J. Parton, and J. Persson. 1992. Modeling soil organic matter in organic-amended and nitrogen-fertilized long-term plots. Soil Sci. Soc. Am. J. 56:476-488.

Perry, E., and G.W. Hickman. 1998. Correlating foliar nitrogen levels with growth in two landscape tree species. J. Arboric. 24:149-153.

-1999. A survey to determine the baseline nitrogen leaf concentration of twenty-five landscape tree species. Slosson Report 1999-2000:1-3.

Picone, L.I., M.L. Cabrera, and A.J. Franzluebbers. 2002. A rapid method to estimate potentially mineralizable nitrogen in soil. Soil Sci. Soc. Am. J. 66:1843-1847.

Poorter, H., and M. Bergkotte. 1990. Chemical composition of 24 wild species differing in relative growth rate. Plant Cell Environ. 15:159-166

Porter, L.K., B.A. Stewart, and H.J. Salas. 1964. Effects of long-time cropping on hydrolyzable organic nitrogen fractions in some Great Plains soils. Soil Sci. Soc. Am. Proc. 28:368-370.

Powlson, D.S., P.C. Brookes, an B.T. Christensen. 1987. Measurement of soil microbial biomass provides an early indication of changes in total soil organic matter due to straw incorporation. Soil Biol. Biochem. 19:159-164.

Pulford, I.D. 1991. Nutrient provision and cycling in soils in urban areas. In Bullock, P., and P.J. Gregory (Eds.). Soils in the urban environment. Blackwell Scientific Publications, Cambridge, MA.

Qafoku, O.S., M.L. Cabrera, W.R. Windham, and N.S. Hill. 2001. Rapids methods to determine potentially mineralizable nitrogen in broiler litter. J. Environ. Qual. 30:217-221.

Qian, P., and J.J. Schoenau. 1995. Assessing nitrogen mineralization from soil organic matter using anion exchange membranes. Fertil. Res. 40:143-148.

Raab, T.K., D.A. Lipson, and R.K. Monson. 1996. Nonmycorrhizal uptake of amino acids by roots of the alpine sedge Kobresia myosuroides: Implications for the alpine nitrogen cycle. Oecologia 108:488-494.

Recous, S., D. Robin, D. Darwis, and B. Mary. 1995. Soil inorganic $\mathrm{N}$ availability: Effect on maize residue decomposition. Soil Biol. Biochem. 27:1529-1538.

Rice, C.W., T.B. Moorman, and M. Beare. 1996. Role of microbial biomass carbon and nitrogen in soil quality, pp 203-215. In Doran, J.W., and A.J. Jones (Eds.). Methods for Assessing Soil Quality. Soil Science Society of America, Madision, WI.
Roberson, E.B, S. Sarig, and M.K. Firestone. 1991. Cover crop management of polysaccharide-mediated aggregation in an orchard soil. Soil Sci. Soc. Am. J. 55:734-739.

Roberts, R.D., and J.M. Roberts. 1984. The selection and management of soils in landscape schemes, pp 99-126. In Bradshaw, A.D., Goode, D.A., and E.H.P. Thorp. (Eds.). Ecology and Design in the Landscape. Blackwell Scientific Publications, Oxford, UK.

Robinson, D. 1996. Resource capture by localized root proliferation: Why do plants bother? Ann. Bot. 77:179-185.

Rosati, A., K.R. Day, and T.M. DeJong. 2000. Distribution of leaf mass per unit area and leaf nitrogen concentration determine partitioning of leaf nitrogen within tree canopies. Tree Phys. 20:271-276.

Rose, M.A. 1999. Nutrient use patterns in woody perennials: implications for increasing fertilizer efficiency in field-grown and landscape ornamentals. HortTechnology 9:21-25.

Rose, M.A., and B. Biernacka. 1999. Seasonal patterns of nutrient and dry weight accumulation in Freeman maple. HortScience 34:91-95.

Rose, M.A., M. Rose, and H. Wang. 1999. Fertilizer concentration and moisture tension affect growth and foliar N, P, and K contents of two woody ornamentals. HortScience 34:246-250.

Salas, A.M., E.T. Elliott, D.G. Westfall, C.V. Cole, and J. Six. 2003. The role of particulate organic matter in phosphorous cycling. Soil Sci. Soc. Am. J. 67:181-189.

Savin, M.C., J.H. Gorres, D.A. Neher, and J.A. Amador. 2001. Uncoupling of carbon and nitrogen mineralization: role of microbivorous nematodes. Soil Biol. Biochem. 33:1463-1472.

Schulze, E.D. 1982. Plant life forms and their carbon, water, and nutrient relations, pp 616-667. In Lange, O.L (Ed.). Physiological Plant Ecology. Springer-Verlag, New York, NY.

Schmidt, I.K., L. Ruess, E. Baath, A. Michelsen, F. Ekelund, and S. Jonasson. 2000. Long-term manipulation of the microbes and microfauna of two subarctic heaths by addition of fungicide, bactericide, carbon and fertilizer. Soil Biol. Biochem. 32:707-720.

Schnitzer, M. 1986. Binding of humic substances by soil mineral colloids, pp 77-101. In Huang, M., and M. Schnitzer (Ed.). Interactions of Soil Minerals with Natural Organics and Microbes. Special publication No. 17. Soil Science Society of America, Madison, WI.

Schnurer, J., M. Clarholm, and T. Rosswall. 1985. Microbial biomass and activity in an agricultural soil with different organic matter contents. Soil Biol. Biochem. 17:611-618.

Schoenholtz, S.H., H.V. Miegroet, and J.A. Burger. 2000. A review of chemical and physical properties as indicators of forest soil quality: Challenges and opportunities. For. Ecol. Man. 138:335-356. 
Scott, N.A., and D. Binkley. 1997. Foliage litter quality and annual net $\mathrm{N}$ mineralization: Comparison across North American forest sites. Oecologia 111:151-159.

Seneviratne, G., L.H.J. Van Holm, L.J.A. Balachandra, and S.A. Kulasooriya. 1999. Differential effects of soil properties on leaf nitrogen release. Biol. Fertil. Soils 28:238-243.

Setala, H., J. Haimi, and A. Siira-Pietikainen. 2000. Sensitivity of soil processes in northern forest soils: Are management practices a threat. For. Ecol. Manage. 133:5-11.

Shiralipour, A., D.B. McConnell, and W.H. Smith. 1992. Physical and chemical properties of soils as affected by municipal solid waste compost application. Biom. Bioenerg. 3:261-266.

Siewert, A., B. Rao, and D.F. Marion. 2000. Tree and Shrub Fertilization: Proceedings from an International Conference on Tree and Shrub Fertilization. 17-18 May 2000. Fairlawn, OH. International Society of Arboriculture, Champaign, IL.

Sikora, L.J., and D.E. Stott. 1996. Soil organic carbon and nitrogen, pp 157-167. In Doran, J.W., and A.J. Jones (Eds.). Methods for Assessing Soil Quality. Soil Science Society of America, Madision, WI.

Sikstrom, U.S., H.-O. Nohrstedt, F. Pettersson, and S. Jacobson. 1998. Stem-growth response of Pinus sylvestris and Picea abies to nitrogen fertilization as related to needle nitrogen concentration. Trees 12:208-214.

Sims, J.T. 1990. Nitrogen mineralization and elemental availability in soils amended with composted sewage sludge. J. Environ. Qual. 19:669-675.

Six, J., E.T. Elliott, K. Paustian, and J.W. Doran. 1998. Aggregation and soil organic matter accumulation in cultivated and native grassland soils. Soil Sci. Soc. Am. J. 62:1367-1377.

Six, J., P. Callewaert, S. Lenders, S. De Gryze, S.J. Morris, E.G. Gregorich, E.A. Paul, and K. Paustian. 2002. Measuring and understanding carbon storage in afforested soils by physical fractionation. Soil Sci. Soc. Am. J. 66:1981-1987.

Smiley, E.T., B.R. Fraedrich, and D.C. Booth. 1991. Comparison of trunk-injected and soil-applied macronutrients. J. Arboric. 17:322-324.

Smiley, T., S. Lilly, and P. Kelsey. 2002a. Fertilizing trees and shrubs, part 1: Determining if, when, and what to use. Arborist News April 2002.

- 2002b. Fertilizing trees and shrubs, part 2: Application techniques. Arborist News June 2002.

Smith, E.M. 1972. A survey of foliar mineral element content of nursery-grown ornamentals. HortScience 7:321.

Smith, M.A.L., A.G. Endress, G.R. Smith, J.E. Lloyd, R.D. Neely, R.K. Stutman, J.J. Ball, K.D. Coder, and T.L. Wadley. 2002. A Guide to the Plant Health Care Management System (3rd ed.). International Society of Arboriculture, Champaign, IL.
Smith, S.J., and L.B. Young. 1975. Distribution of nitrogen forms in virgin and cultivated soils. Soil Sci. 120:354-360.

Sohn Lopez-Forment, I. 2000. Ecological and socio-cultural dynamics of traditional and legume based MILPA agriculture in southeast Mexico. Ph.D. dissertation. The Ohio State University, Columbus, $\mathrm{OH}$.

Sparling, G.P. 1992. Ratio of microbial biomass carbon to soil organic carbon as a sensitive indicator of changes in soil organic matter. Aust. J. Soil Res. 30:195-207.

Spycher, G., P. Sollins, and S. Rose. 1983. Carbon and nitrogen in the light fraction of a forest soil: Vertical distribution and seasonal patterns. Soil Sci. 135:79-87.

Stamatiadis, S., M. Werner, and M. Buchanan. 1999. Field assessment of soil quality as affected by compost and fertilizer application in a broccoli field (San Benito County, California). Appl. Soil Ecol. 12:217-225.

Stanford, G., and S.J. Smith. 1972. Nitrogen mineralization potentials of soils. Soil Sci. Soc. Am. Proc. 36:465-472.

Stinner, B.R., D. McCartney, and E.R. Zaborski. 2002. Role of labile soil organic matter and soil microbial biomass in nitrogen cycling processes across a range of soil conditions and management history in northeastern Ohio. Proceedings, International Symposium on Composting and Compost Utilization, 6-8 May 2002, Columbus, $\mathrm{OH}$.

Stone, A.G., S.J. Traina, and H.A.J. Hoitink. 2001. Particulate organic matter composition and pythium damping-off of cucumber. Soil Sci. Soc. Am. J. 65:761-770.

Stroo, H.F, and E.M. Jencks. 1982. Enzyme activity and respiration in mine spoils. Soil Sci. Soc. Am. J. 46:548-553.

Struve, D. 2002. A review of shade tree nitrogen fertilization in the United States. J. Arboric. 28:252-263.

Stump, L.M., and D. Binkley. 1993. Relationships between litter quality and nitrogen availability in Rocky Mountain forests. Can. J. For. Res. 23:492-502.

Sullivan, D.M., A.I. Bary, D.R. Thomas, S.C. Fransen, and C.G. Cogger. 2002. Food waste compost effects on fertilizer nitrogen efficiency, available nitrogen, and tall fescue yield. Soil Sci. Soc. Am. J. 66:154-161.

Tisdale, J.M., and J.M. Oades. 1982. Organic matter and water-stable aggregates in soils. J. Soil Sci. 33:141-163.

Tisdale, S.L., W.L. Nelson, and J.D. Beaton. 1985. Soil Fertility and Fertilizers (4th ed.). Macmillan, New York, NY.

Van der Werken, H. 1981. Fertilization and other factors enhancing the growth rate of young shade trees. J. Arboric. 7:33-37.

Van Gestel, M., J.N. Ladd, and M. Amato. 1992. Microbial biomass responses to seasonal change and imposed drying regimes at increasing depths of undisturbed topsoil profiles. Soil Biol. Biochem. 24:103-111.

Van Veen, J.A., and E.A. Paul. 1981. Organic carbon dynamics in grassland soils. I. Background information and computer simulation. Can. J. Soil Sci. 61:185-201. 
Varlamoff, S., W.J. Florkowski, J.L. Jordan, J. Latimer, and K. Braman. 2001. Georgia homeowner survey of landscape management practices. HortTechnology 11:326-331.

Verchot, L.V., Z. Holmes, L. Mulon, P.M. Groffman, and G.M. Lovett. 2001. Gross vs. net rates of N mineralization and nitrification as indicators of functional differences between forest types. Soil Biol. Biochem. 33:1889-1901.

Vitousek, P.M., and R.W. Howarth. 1991. Nitrogen limitation on land and in the sea: How can it occur? Biogeochemistry 13:87-115.

Warren, S.L. 1993. Growth and nutrient concentration in flowering dogwood after nitrogen fertilization and dormant root pruning. J. Arboric. 19:57-63.

Watson, G.W. 1994. Root growth response to fertilizers. J. Arboric. 20:4-8.

Weinert, T.L., T.L. Thompson, S.A. White, and M.A. Maurer. 2002. Nitrogen fertigation of young navel oranges: Growth, N status, and uptake of fertilizer N. HortScience 37:334-337.

Wood, C.W., D.W. Reeves, R.R. Duffield, and K.L. Edmisten. 1992. Field chlorophyll measurements for evaluation of corn nitrogen status. J. Plant Nutr. 15:487-500.

Wright, C.J., and D.C. Coleman. 2002. Responses of soil microbial biomass, nematode trophic groups, Nmineralization, and litter decomposition to disturbance events in the southern Appalachians. Soil Biol. Biochem. 34:13-25.

Yeager, T.H., and R.D. Wright. 1981. Influence of nitrogen and phosphorous on shoot:root ratio of Ilex crenata Thunb. "Helleri". HortScience 16:564-565.
Zerihun, A., B.A. McKenzie, and J.D. Morton. 1998. Photosynthate costs associated with the utilization of different nitrogen-forms: influence on the carbon balance of plants and shoot-root biomass partitioning. New Phytol. 138:1-11.

Zhu, W.-X. and M.M. Carreiro. 1999. Chemoautotrophic nitrification in acidic forest soils along an urban-to-rural transect. Soil Biol. Biochem. 31:1091-1100.

Acknowledgments. The authors thank Jodi Johnson-Maynard, Ph.D., Richard Gill, Ph.D., Donn Thill, Ph.D., Robert Tripepi, Ph.D., and two anonymous reviewers for their suggestions. We also thank the TREE Fund (John Duling Grant) and the University of Idaho Seed Grant for their support of this project.

${ }^{1 *}$ Graduate Research Assistant

Department of Soil Science

College of Agricultural and Life Sciences

University of Wisconsin-Madison

Madison, WI 53706-1299, U.S.

${ }^{2}$ Assistant Professor of Arboriculture

Department of Plant, Soil, and Entomological Sciences

College of Agriculture and Life Science

University of Idaho

P.O. Box 442339

Moscow, ID 83844-2339, U.S.

*Corresponding author. 
Résumé. Les gestionnaires d'aménagements urbains doivent maintenir les qualités esthétiques des végétaux et, de ce fait, doivent s'assurer que les plantes ont suffisamment d'azote pour leur croissance et leur réussite. Les premiers facteurs déterminants de la disponibilité en azote sont la décomposition de la matière organique dans le sol ainsi que la minéralisation de l'azote produite par les micro-organismes du sol. De ce fait, les recherches quant aux contenus en azote du sol, en matière organique et en populations microbiennes dans le sol devraient aider les gestionnaires d'aménagements paysagers en milieu urbain à raffiner leurs outils de diagnostic et leurs prescriptions en fertilisation pour les végétaux urbains. Les analyses foliaires peuvent être utilisées pour mesurer l'azote que les plantes ont acquises, mais cela ne révèle pas d'informations quant aux besoins actuels ou futurs des végétaux en azote. Les analyses d'azote du sol peuvent être utilisées pour mesurer la quantité courante d'azote disponible pour assimilation par la plante tout comme la quantité qui pourra être potentiellement disponible à un moment donné dans le futur. Les changements dans la quantité totale de matière organique se produisent de manière primaire au niveau des fractions de particules de la matière organique, et des corrélations positives ont été identifiées entre l'azote des particules de la matière organique, l'azote microbienne du sol et l'azote qui peut potentiellement être minéralisée dans le sol. Conséquemment, des examens des fractions des particules de la matière organique sont des indicateurs potentiels des changements dans la matière organique du sol et de la disponibilité en azote. Afin d'améliorer les standards dans la détermination du statut de l'azote et les besoins des végétaux dans les aménagements urbains, l'évaluation en azote dans le sol et les plantes doit être améliorée et corrélée entre la demande en azote des végétaux et l'azote contenu dans le sol.

Zusammenfassung. Von den Stadt- und Landschaftsplanern wird verlangt, die ästhetischen Qualitäten der Pflanzen beizubehalten und deshalb muss sichergestellt sein, dass die Vegetation adäquate Stickstoffversorgung hat, um zu wachsen und zu gedeihen. Die Dekompostierung organischer Substanz und die Mineralisation von Stickstoff durch Bodenorganismen sind die primären Faktoren der Stickstoffverfügbarkeit. Daher sollen Untersuchungen über den Bodenstickstoffgehalt, organische Substanz und Aktivität von Bodenorganismen die Manager in die Lage versetzen, die diagnostischen Werkzeuge und die Düngung zu verbessern. Blattuntersuchungen können genutzt werden, den erforderlichen Stickstoffbedarf zu ermitteln, aber sie ergeben keine Informationen über den gegenwärtigen oder zukünftigen Bedarf. Die Bodenstickstoffanalyse kann verwendet werden, um den gegenwärtigen pflanzenverfügbaren Bodenstickstoff und auch den möglicherweise zukünftig verfügbaren Stickstoff zu messen. Änderungen in der totalen organischen Substanz tauchen in der POM-Fraktionen auf und es konnten positive Korrelationen zwischen diesen, dem mikrobiellen Bodenstickstoff und den potentiell mineralisierbaren Stickstoff identifizieret werden. Demzufolge können Untersuchungen der POM-Fraktionen mögliche Veränderungen in der organischen Substanz und der Stickstoffverfügbarkeit anzeigen. Um die existierenden Standards für die Bestimmung des Stickstoffgehalts und die Ansprüche der Stadtpflanzen zu verbessern, muss die Boden- und Pfanzenstickstoffbewertung verbessert und mit dem Pflanzenstickstoffbedarf und der Bodenstickstoffverfügbarkeit korreliert werden.

Resumen. Los manejadores del paisaje urbano son requeridos para mantener la calidad estética de las plantas y asegurar que la vegetación mantenga el nitrógeno adecuado para crecer y florecer. La descomposición de la materia orgánica y la mineralización del nitrógeno facilitado por los microorganismos del suelo son los determinantes primarios de disponibilidad de nitrógeno del suelo. De ahí que de las investigaciones de fuentes de nitrógeno en el suelo, materia orgánica y poblaciones microbianas deben ayudar a los manejadores del paisaje a refinar las herramientas de diagnóstico y prescripción de fertilización para la vegetación urbana. Los análisis foliares pueden ser usados para medir el nitrógeno que las plantas ha adquirido, pero no dan información acerca de la adquisición actual o futura del mismo. Los análisis del suelo pueden ser usados para medir el nitrógeno disponible en el momento para las plantas, como también la cantidad potencialmente disponible en el futuro. Los cambios en el nitrógeno total de la materia orgánica en el suelo ocurren primariamente en las fracciones o partículas de materia orgánica (PMO) y se han identificado correlaciones positivas entre el nitrógeno PMO, nitrógeno microbiano del suelo y nitrógeno potencial mineralizable. Consecuentemente, los exámenes de las fracciones PMO indican cambios en la materia orgánica del suelo y la disponibilidad de nitrógeno. Con el fin de mejorar los estándares existentes para la determinación del estado del nitrógeno y las necesidades de las plantas en ambientes urbanos, la evaluación del nitrógeno en las plantas debe ser mejorada y correlacionada con la demanda de nitrógeno y el aporte del mismo por el suelo. 